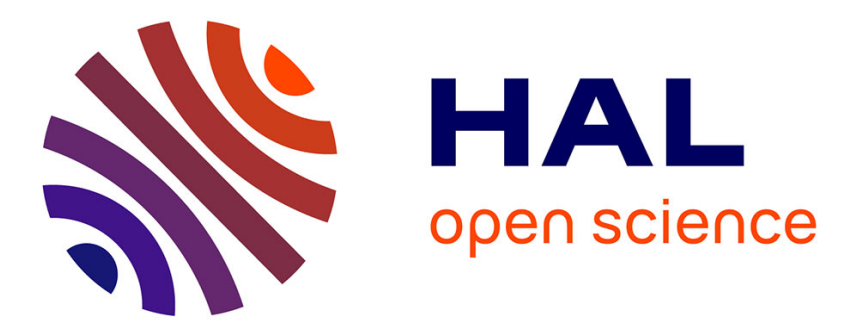

\title{
Influence of the calf presence during milking on dairy performance, milk fatty acid composition, lipolysis and cheese composition in Salers cows during winter and grazing seasons
}

Anamaria Cozma, Bruno Martin, Carole Cirie, Isabelle Verdier-Metz, Jacques Agabriel, Anne Ferlay

\section{To cite this version:}

Anamaria Cozma, Bruno Martin, Carole Cirie, Isabelle Verdier-Metz, Jacques Agabriel, et al.. Influence of the calf presence during milking on dairy performance, milk fatty acid composition, lipolysis and cheese composition in Salers cows during winter and grazing seasons. Journal of Animal Physiology and Animal Nutrition, 2016, 105 (5), 10.1111/jpn.12530 . hal-01594523

\author{
HAL Id: hal-01594523 \\ https://hal.science/hal-01594523
}

Submitted on 26 Sep 2017

HAL is a multi-disciplinary open access archive for the deposit and dissemination of scientific research documents, whether they are published or not. The documents may come from teaching and research institutions in France or abroad, or from public or private research centers.
L'archive ouverte pluridisciplinaire HAL, est destinée au dépôt et à la diffusion de documents scientifiques de niveau recherche, publiés ou non, émanant des établissements d'enseignement et de recherche français ou étrangers, des laboratoires publics ou privés. 


\title{
Influence of the calf presence during milking on dairy performance, milk fatty acid composition, lipolysis and cheese composition in Salers cows during winter and grazing seasons
}

\author{
A. Cozma ${ }^{1,2,3}$, B. Martin ${ }^{1,2}$, C. Cirié ${ }^{4}$, I. Verdier-Metz ${ }^{5}$, J. Agabriel ${ }^{1,2}$ and A. Ferlay ${ }^{1,2}$ \\ 1 UMR 1213 Herbivores, INRA, Saint-Genès-Champanelle, France \\ 2 UMR Herbivores, VetAgro Sup, Clermont-Ferrand, France \\ 3 Department of Bromatology, Hygiene, Nutrition, Faculty of Pharmacy, 'Iuliu Haţieganu' University of Medicine and Pharmacy, Cluj-Napoca, Romania \\ 4 UE1296 Monts d'Auvergne, INRA, Orcival, France, and \\ 5 UR545 Fromagères, INRA, Aurillac, France
}

\section{Summary}

The milking of Salers cows requires the presence of the calf. The removal of the calf would simplify the milking routine, but it could also modify the milk yield and the milk and cheese composition. Therefore, the aim of this experiment was to evaluate the effect of calf presence during milking during sampling period (winter or grazing periods), on dairy performance, milk fatty acid (FA) composition, lipolysis and cheese yield and composition. Nine and 8 Salers lactating cows were milked in the presence (CP) or absence (CA) of their calves respectively. During winter, the cows were fed a hay-based diet and then they only grazed a grassland pasture. Calf presence during milking increased milk yield and milk 16:0 concentration and decreased milk fat content and milk total odd- and branched-chain FA (OBCFA) concentrations. Calf presence only increased initial lipolysis in milk collected during the winter season. Milk from CP cows compared to CA cows resulted in a lower cheese yield and ripened cheeses with lower fat content. Milk from the grazing season had lower saturated medium-chain FA and OBCFA concentrations and higher 18:0, cis-9-18:1, trans-11-18:1 and cis-9, trans-11-CLA concentrations than that from the winter season. Initial milk lipolysis was higher in the winter than in the grazing season. These variations could be due to seasonal changes in the basal diet. Furthermore, the effect of calf presence during milking on milk fat composition was lower than that on dairy performance, cheese yield and composition. Removing the calf during the milking of Salers cows seems feasible without a decrease in milked milk, and with a positive effect on cheese yield and fat content, under the condition that we are able to select cows having the capacity to be milked easily without the calf.

Keywords dairy cow, Salers breed, calf presence, season, milk fatty acids, cheesemaking

Correspondence A. Ferlay, UMR 1213 Herbivores, INRA, F-63122 Saint-Genes-Champanelle, France. Tel.: +33 473 624513; Fax: +33 473 624519;

E-mail: anne.ferley@clermont.inra.fr

Received: 6 October 2015; accepted: 8 April 2016

\section{Introduction}

The Salers cow breed is a dual-purpose breed originating from the Auvergne region of central France. Currently, the 205000 Salers cows recorded are reared primarily in suckling systems, whereas only $2 \%$ of the French population of Salers cows are still milked (Institut de l'Elevage, 2011). These Salers cows are only located in Auvergne where their milk is mostly used for the production of traditional cheeses (Cantal, Salers and Saint-Nectaire) labelled with a protected designation of origin (PDO). The rapid decrease in the number of milked Salers cows is related to their low production level (2321 kg/lactation) (Institut de
l'Elevage, 2011) and to the process of milking, referred as 'traditional', that requires the presence of the calf to stimulate milk ejection (Tournadre et al., 2008). As this traditional milking is time-consuming, an option to overcome this inconvenience and simplify the milking routine could be the suppression of cow-calf contact. Therefore, it is essential to evaluate the impact of this milking strategy on the dairy performance because these aspects are poorly documented in the literature. The available published data state that removing the calf during milking decreases the milk production $(-5.6 \mathrm{l} / \mathrm{d})$ of Salers cows and increases the protein and fat contents (Cozma et al., 2013; Agabriel et al., 2014). Moreover, removing the 
calf during milking could modify the cheesemaking ability of milk and the chemical composition of resulting cheeses. Furthermore, previous studies in Salers and Prim'Holstein cows suggest a possible influence of cow-calf contact during milking on fatty acids (FA) profile in bulk milks (Cozma et al., 2013), but this effect has never been validated on individual milks. This information is important because this milking treatment could modify the lipid metabolism of the dairy cows, and thus, the dairy performance, milk FA composition and lipolysis (Chilliard and Ferlay, 2004).

Furthermore, previous studies indicate that milk FA profile is markedly influenced by the nature of forage (preserved vs. grazed grass) in ruminant diet (Ferlay et al., 2006; Chilliard et al., 2007). Cow diet could also have an effect on milk lipolytic system. It has been shown that grass-based diets have an influence on the milk lipolytic system in mid-lactating Tarentaise and Montbéliarde cows (Ferlay et al., 2006), but this factor received only little attention in dairy Salers cows (Cozma et al., 2013).

Therefore, the aim of this study was to evaluate the effect of calf presence during milking in winter and grazing seasons, on dairy performance, with particular emphasis on milk FA concentrations and lipolysis. Moreover, the study aimed to evaluate the effect of presence or absence of the calf on the yield and chemical composition of cheese.

\section{Materials and methods}

\section{Cows and diets}

The study was conducted between November 2010 and June 2011 at the 'Institut National de la Recherche Agronomique' (INRA) experimental farm of Marcenat in an upland area of central France (altitude 1135-1215 m; annual rainfall $1100 \mathrm{~mm}$ ) using a protocol approved by the INRA Animal Care and Use Committee. All procedures were conducted according to French guidelines for the use of experimental animals compliant with animal welfare and good practices (Veissier, 1999).

Seventeen Salers lactating cows (body weight (BW) $637 \mathrm{~kg}$ at the beginning of the lactation period) were selected before parturition and assigned to two groups according to parity (eight primiparous and nine multiparous), expected calving date, potential milk yield (defined for primiparous as the best milk yield during an entire lactation of the mother plus one-half of the best milk yield of the paternal grandmother as recorded by the Recording Milk Organisation), BW and body condition score (BCS). One group of Salers cows was milked in the presence of the calf $(\mathrm{CP}$, $n=9$, with three primiparous and six multiparous, and with $\mathrm{BW}=643 \pm 70 \mathrm{~kg}$ and BCS $=2.86 \pm 0.45$, around calving) and a second group of Salers cows was milked in the absence of the calf (CA, $n=8$, with five primiparous and three multiparous, and with $\mathrm{BW}=629 \pm 39 \mathrm{~kg}$ and $\mathrm{BCS}=3.00 \pm 0.29$, around calving). Because it was difficult to maintain the cows milked without the calf in lactation during a long period (Agabriel et al., 2014), we have introduced in the CA group more primiparous females in order to maintain the same number of animals between the two groups. The cows entered successively in the experiment after calving (calving dates between October 22, 2010 and December 17, 2010) such that the average calving date of the two groups was similar (November 10, 2010 and November 9, 2010 for the CP and CA groups respectively).

The cows were housed in five pens and the calves in a separate pen located in the same building. The cows were machine-milked in a milking parlour twice daily, at 6:30 and 16:00. For cows milked in the presence of the calf, the mother-calf pair remained together $24 \mathrm{~h}$ after parturition, with cows being milked at the usual hours. At the end of the second milking, the young returned to the calf pen, and the dam was placed into the cow pen. For these cows, milking included a phase of calf suckling before milking (for 30-60 s). The calf was then placed in a pen in front of the mother during milking. Physical contact was allowed. At the end of milking, the mother-calf pair was placed in a pen, and calves were allowed to suckle their mother for approximately $5 \mathrm{~min}$ to completely empty the udder. After the suckling, the mother-calf pair was separated. The mother returned to the cow pen and the young to the calf pen respectively. For the cows milked in the absence of the calf, the newborn calves were separated from their mother immediately after parturition, without any sniffing, licking or suckling.

Before calving, all cows were fed the same diet, consisting of grassland hay offered ad libitum. After calving, feed distribution continued to be performed collectively, and the cows were secured with headlocking stanchions. The intake amounts were measured, on average, from two pens per group. The feedstuffs distributed per pen were weighed daily. Any refusals were collected and weighed daily for 2 days each week (twice per day) to calculate the net intake of each group. Forage distributed consisted in $6 \mathrm{~kg}$ of grassland hay (regrowth) per animal after morning milking and grassland hay (first cut) offered ad libitum in the afternoon. Cows were fed concentrate during the morning and afternoon milkings according to their daily milk production: $4 \mathrm{~kg} /$ day 
concentrate for a milk yield ranging from 4 to $11 \mathrm{~kg} /$ day and 5, 6 and $7 \mathrm{~kg} /$ day for milk yield ranging from $11-14,14-16$ and $>16 \mathrm{~kg} /$ day respectively. The diets were formulated to cover $100 \%$ of the energy and protein requirements according to INRA (2007). The nutritive value of the feedstuffs is shown in Table 1.

On 26th April, the cows were turned out to pasture. They received no further concentrate until 31st October. The cows grazed successive paddocks of grassland pastures according to a rotational grazing management. From 21 May through 25 May, they had access to a paddock with a 1.81-ha area of grassland pasture at a low stocking density (0.07 livestock unit (LU)/ha; $1 \mathrm{LU}=600 \mathrm{~kg} \mathrm{BW})$. They remained at pasture throughout the day and night. The pasture grazed consisted of $82 \%$ grasses (primarily $22 \%$ Dactylis glomerata, 26\% ryegrass, $11 \%$ Poa pratensis), 1\% legumes (essentially clover) and 17\% dicots.

\section{Sampling, measurement and analyses}

Samples of grassland hay (first cut and regrowth) and concentrate were collected twice per week during the experimental period (November 2010 - June 2011), and then pooled to provide one sample per each 2 -month period and stored at $-20{ }^{\circ} \mathrm{C}$. The DM concentration of the feed was determined after drying at $105{ }^{\circ} \mathrm{C}$ for $24 \mathrm{~h}$. Samples of grassland hay (first cut and regrowth) and concentrate were lyophilised, sieved through a $1-\mathrm{mm}$ screen and analysed for total crude protein, crude fibre, acid-detergent fibre (ADF) and organic matter $(\mathrm{OM})$ using standard procedures (AOAC, 1997). The FA composition was determined from ground lyophilised feedstuff samples using a one-step extraction and methylation procedure as described by Sukhija and Palmquist (1988) and using tricosanoate (Sigma, Saint-Quentin-Fallavier, France) as the internal standard added into each sample before lipid extraction.

During the entire experiment, milk suckled by the calves was determined twice per week (on Tuesday and Wednesday each week), over four consecutive milkings, by the differences between calf body weights before and after suckling (Le Neindre and Dubroeucq, 1973). Milked milk was recorded individually at each milking with a continuous milk weighing system. One

Table 1 Chemical composition of feedstuffs included in the diet distributed to Salers cows

\begin{tabular}{|c|c|c|c|c|c|}
\hline Ingredients & Concentrate* & Grazed grass & $\begin{array}{l}\text { Hay (first cut) } \\
\text { distributed from } \\
\text { November to March 9th }\end{array}$ & $\begin{array}{l}\text { Hay (first cut) } \\
\text { distributed from } \\
\text { March 10th to April 26th }\end{array}$ & Hay (regrowth) \\
\hline Crude Protein (g/kg) & 61 & - & 104 & 93 & 136 \\
\hline $\mathrm{OM}(\mathrm{g} / \mathrm{kg})$ & 945 & - & 922 & 933 & 917 \\
\hline Net energy (MJ/kg of DM) & 6.96 & - & 5.19 & 5.19 & 4.97 \\
\hline Crude Fibre (g/kg of DM) & 79 & - & 358 & 348 & 335 \\
\hline ADF (g/kg of DM) & - & - & 345 & 355 & 310 \\
\hline \multicolumn{6}{|c|}{ Fatty acid (g/100 g of total FA) } \\
\hline $12: 0$ & 0.033 & 0.121 & 0.250 & 0.904 & 0.408 \\
\hline 14:0 & 0.187 & 0.412 & 0.693 & 0.655 & 0.830 \\
\hline cis-9-14 :1 & 0.071 & 0.135 & - & - & 0.197 \\
\hline $15: 0$ & 0.146 & 0.111 & 0.227 & 0.262 & 0.202 \\
\hline iso $16: 0$ & 0.021 & 4.913 & 6.539 & 6.054 & 7.880 \\
\hline $16: 0$ & 15.99 & 14.19 & 23.33 & 23.69 & 24.89 \\
\hline cis-9-16:1 & 0.452 & 0.141 & 0.404 & 0.397 & 0.433 \\
\hline $17: 0$ & 0.126 & 0.168 & 0.230 & - & 0.384 \\
\hline $18: 0$ & 1.57 & 1.20 & 1.81 & 1.64 & 2.18 \\
\hline cis-9-18:1 & 24.66 & 2.12 & 2.63 & 2.56 & 2.51 \\
\hline cis-11-18:1 & 3.13 & 0.36 & 0.52 & 0.52 & 0.65 \\
\hline $18: 2 n-6$ & 47.38 & 15.08 & 17.86 & 17.75 & 13.10 \\
\hline $18: 3 n-3$ & 4.94 & 58.38 & 39.41 & 40.96 & 40.02 \\
\hline $20: 0$ & 0.311 & 0.486 & 1.223 & 1.016 & 1.147 \\
\hline $22: 0$ & 0.358 & 0.769 & 1.634 & 1.230 & 1.614 \\
\hline $24: 0$ & 0.418 & 0.593 & 1.486 & 1.228 & 1.435 \\
\hline $22: 5 n-3$ & 0.212 & 0.812 & 1.747 & 1.130 & 2.133 \\
\hline
\end{tabular}

OM, organic matter; DM, dry matter; ADF, acid-detergent fibre; -, not determined.

${ }^{*}$ Concentrate (g/kg of DM): barley (263.5), wheat bran (200), triticale (150), rapeseed meal (136), wheat (50), sunflower meal (48), molassed sugar beet (20), rapeseed (15), salt (1) and $\mathrm{CaCO}_{3}(9)$. 
set of 30-ml subsamples was collected for individual cows from four consecutive milkings each week (four milk samples per cow) during the entire experiment and was preserved in tubes with bronopol-B2 (Trillaud, Surgères, France) and stored at $4{ }^{\circ} \mathrm{C}$ until analysis for fat, protein, lactose contents and somatic cell counts (SCC) using infrared spectrophotometry (LIAL, Aurillac, France) according to standard procedures (AOAC (Association of Official Analytical Chemists), 1997).

A second set of 3-ml subsamples from two consecutive milkings for FA analyses was collected for individual cows three times during the experimental period: in the 9th week of lactation (after the lactation peak when the energy balance begins to be positive and during winter season), on March 16, 2011 (when the energy balance is positive and during winter season), and on May 25, 2011, 1 month after turning out to pasture (during grazing season). These subsamples were stored at $-20{ }^{\circ} \mathrm{C}$ before lyophilisation (ThermovacTM-20, Froilabo, Ozoir-La-Ferrière, France). Lyophilised samples from the morning and evening milks were pooled (60 and $40 \mathrm{mg}$ of morning and evening samples, respectively, based on the AM and PM milk production, according to Ferlay et al. (2013)) to provide a daily composite sample for each cow. The milk FA composition was determined according to Ferlay et al. (2010) with some modifications. The FA in the lyophilised milk samples were methylated directly: $2 \mathrm{ml}$ of $0.5 \mathrm{~mol} / \mathrm{l}$ sodium methanolate and $1 \mathrm{ml}$ hexane were mixed with the lyophilised milk at $50{ }^{\circ} \mathrm{C}$ for $15 \mathrm{~min}$, followed by the addition of $1 \mathrm{ml}$ $12 \mathrm{~N} \mathrm{HCl} 5 \%$ in methanol $(\mathrm{v} / \mathrm{v})$ at $50{ }^{\circ} \mathrm{C}$ for $15 \mathrm{~min}$. The FA methyl esters (FAME) were washed with a saturated $\mathrm{K}_{2} \mathrm{CO}_{3}$ solution and recovered with $1.5 \mathrm{ml}$ hexane. The FAME were injected $(0.6 \mu \mathrm{l})$ by autosampler into a gas chromatograph equipped with a flame ionisation detector (Agilent Technologies $7890 \mathrm{~A}$, Wilmington, USA). The FAME from all the samples were separated on a $100 \mathrm{~m} \times 0.25 \mathrm{~mm}$ i.d. fused-silica capillary column (CP-Sil 88, Chrompack, Middelburg, the Netherlands). The injector temperature was maintained at $255^{\circ} \mathrm{C}$ and the detector temperature at $260{ }^{\circ} \mathrm{C}$. The initial oven temperature was held at $70{ }^{\circ} \mathrm{C}$ for $1 \mathrm{~min}$, increased to $100{ }^{\circ} \mathrm{C}$ at a rate of $5{ }^{\circ} \mathrm{C} / \mathrm{min}$ (held for $2 \mathrm{~min}$ ), and then increased by $10{ }^{\circ} \mathrm{C} / \mathrm{min}$ to $175^{\circ} \mathrm{C}$ (held for $42 \mathrm{~min}$ ), and $5{ }^{\circ} \mathrm{C} / \mathrm{min}$ to a final temperature of $225^{\circ} \mathrm{C}$ (held for $15 \mathrm{~min}$ ). The carrier gas was hydrogen, and pressure was maintained constant $(158.6 \mathrm{kPa})$ during analysis. A reference standard butter (CRM 164, Commission of the European Communities, Community Bureau of Reference, Brussels, Belgium) was used to estimate correction factors for short-chain FA (C4:0 to C10:0). Identification of FAME was accomplished by comparison to a standard mixture purchased by Nu-ChekPrep, Inc (Elysian, MN 56028 USA). Mixtures of cis/ trans (9-12) isomers of linoleic acid methyl ester and cis and trans (9-11) and (10-12) isomers of CLA methyl esters purchased by Sigma-Aldrich Corporation (38297 Saint-Quentin-Fallavier, France) were used to complete identification.

A third set of 70-ml subsamples was taken for individual cows in duplicate three times during the experimental period at morning milking on the same sampling dates used for milk FA composition to evaluate milk lipolysis by the determination of initial FFA content (lipolysis at $\mathrm{t}_{0}$ ) and FFA content after $24 \mathrm{~h}$ of cold storage $\left(4{ }^{\circ} \mathrm{C}\right)$ (lipolysis at $\left.\mathrm{t}_{24}\right)$. The milk lipolytic system was evaluated by the copper soap method (Jellema et al., 1991). A fourth set of subsamples (30 ml, obtained by pooling 60 and $40 \mathrm{mg}$ of morning and evening samples, respectively) for individual cows from two consecutive milkings on the same sampling dates as for milk FA composition was frozen at $-20{ }^{\circ} \mathrm{C}$ prior to analysis of milk LPL activity. Milk LPL activity was measured using an artificial emulsion containing ${ }^{3} \mathrm{H}$ triolein emulsion (Faulconnier et al., 1994).

\section{Cheesemaking}

At each cheesemaking date, bulk milk was collected from four consecutive milkings (morning and evening, on two consecutive days). Bulk milk samples $(30 \mathrm{ml})$ were preserved in tubes with bronopol-B2 (Trillaud, Surgères, France) and stored at $4{ }^{\circ} \mathrm{C}$ until analysis (AOAC (Association of Official Analytical Chemists), 1997).

The morning bulk milk was pooled with the previous evening bulk milk stored at $4{ }^{\circ} \mathrm{C}$. Eight series of small-size Cantal cheeses $(10 \mathrm{~kg})$ were manufactured from CP and CA bulk milks: four cheeses from native CP milk and four cheeses from native CA milk were made on January 11, 17, 25 and 31, 2011, and 4 cheeses from standardised CP milk and 4 cheeses from standardised CA milk were made on January 13, 18, 27 and February 2, 2011. The aim of milk standardisation, performed by partial skimming or by addition of cream of milk obtained from the same group, was to approach a fat-to-protein ratio of 1 . On each cheesemaking date, cheeses were manufactured from $100 \mathrm{l}$ of CP or CA bulk milk in parallel in two vats (one cheese per vat). In each vat, the milk was heated to $33{ }^{\circ} \mathrm{C}$ and rennetted with $0.33 \mathrm{~g} / \mathrm{kg}$ of a rennet (Beaugel 500, Villefranche sur Saone, France) containing $500 \mathrm{mg}$ of active chymosin per litre. Forty-five 
minutes later, the curd was cut for 5 min to produce pellets with 5- to 6-mm diameter. The curd-whey mixture was then blended for $12 \mathrm{~min}$ and left to stand for 5-10 min. After draining the whey, the curd was placed in a pressing tray where it was pressed for $1.5 \mathrm{~h}$, during which it underwent eight turnarounds and as many cuttings. After pressing, the curd cubes were left to drain for $22 \mathrm{~h}$, and then they were pounded. The mixture was salted $(20 \mathrm{~g} / \mathrm{kg})$ and left to stand for $3 \mathrm{~h}$ before one cheese per vat was formed in a cloth mould and pressed for $24 \mathrm{~h}$. The fresh cheeses thus obtained were placed in a ripening cellar for 22 weeks at $10{ }^{\circ} \mathrm{C}$ and $95 \%$ minimum relative humidity. Cheeses were then sampled for analyses. Dry matter (DM) and fat content were measured using the method proposed by Rowland (1938). Gross cheese yield was calculated as cheese weight/100 kg of milk $\times 100$, and the dry cheese yield was calculated as cheese yield $\times$ cheese DM/100. Cheeses were weighed after 3.5 months of ripening.

\section{Statistical analyses}

Data on time-dependent changes were analysed as repeated measures using the MIXED procedure of SAS (Statistical Analysis System) (2003). The statistical model included treatment (CP or CA), sampling period (three dates), parity (primiparous vs. multiparous), treatment $\times$ sampling period, parity $\times$ sampling period and treatment $\times$ sampling period $\times$ parity interactions, and residual error. The effects of treatment, sampling period, parity and their interactions were considered as fixed effects. Cow was included as a random effect. A compound symmetry error structure was used because it resulted in the lowest Bayesian information criterion. Differences between treatment, parity, sampling period and interactions were analysed with the least square means procedure (SAS, 2003) and were considered to be significant if $P \leq 0.05$.

Data on the bulk milk or cheese composition were analysed by the MIXED procedure of SAS (2003), with treatment (CP or CA), milk nature (native or standardised) and their treatment $\times$ milk nature interaction as fixed effects, and day of cheesemaking as random effect.

\section{Results}

Characteristics of animals, milk yield and composition The results for milk yield and composition and the characteristics of the experimental animals are given in Table 2.
Effect of calf presence during milking

On average, during the three sampling periods, the total milk yield of the CP cows was higher than that of the CA cows $(+43 \%, 13.1$ and 7.5 l/day for the CP and CA cows, respectively; $\mathrm{p}<0.01$ ), but the milked milk was similar. The total $(p<0.05)$ and milked $(p<0.01)$ milks were higher in the presence of the calf during the 3 successive sampling dates. The decrease in these milks was more important for CA than for CP groups (treatment $\mathrm{x}$ sampling date interaction, $\mathrm{p}<0.05)$. The milked milk from CP cows had a lower milk fat content $(p<0.001)$ and SCC $(p<0.05)$ than that of CA cows. The milk protein content was slightly lower in the CP group during the winter season and slightly higher during the grazing season $(\mathrm{p}<0.05)$. The BCS was higher in CA cows than in CP cows $(\mathrm{p}<0.01)$.

\section{Effect of sampling period}

The milk yield of the cows was lower $(p<0.001)$ and the fat $(p<0.001)$ and protein $(p<0.001)$ contents of the milks and SCC $(\mathrm{p}<0.05)$ were higher during the grazing season. The BW increased from the 9th week of lactation to March and then decreased from March to the grazing season $(p<0.001)$.

\section{Effect of parity}

The multiparous cows had a higher BW than the primiparous cows (on average $72.2 \mathrm{~kg}, \mathrm{p}<0.05$ ) and tended to have a higher BCS $(p=0.10)$.

\section{Milk fatty acid composition}

\section{Effect of calf presence during milking}

Calf presence during milking increased the milk 14:0 $(\mathrm{p}<0.01)$, cis-9-10:1 ( $\mathrm{p}<0.05)$, cis-9-16:1 ( $<<0.05)$, cis-11-16:1 $(\mathrm{p}<0.001)$ and trans-9, trans-11-CLA $(p<0.05)$ concentrations. In contrast, calf presence during milking significantly decreased the milk total $(\mathrm{p}<0.01)$ and individual odd- and branched-chain FA (OBCFA) concentrations [iso 13:0 (p<0.01), 15:0 $(\mathrm{p}<0.05)$, anteiso 15:0 $(\mathrm{p}<0.01)$, iso 15:0 $(\mathrm{p}<0.01)$, iso 16:0 $(\mathrm{p}<0.01)]$, and 20:0 $(\mathrm{p}<0.01)$, cis-6-18:1 $(\mathrm{p}<0.01), \quad$ cis-14-18:1 $\quad(\mathrm{p}<0.05), \quad$ trans-11-18:1 $(\mathrm{p}<0.05)$ and total trans-18:1 $(\mathrm{p}<0.01)$ concentrations (Tables 3 and 4).

\section{Effect of sampling period}

Except for 4:0, iso 13:0, cis-11-16:1, trans-9-16:1, trans9, trans-11-CLA, 18:3 n-3, 20:2 n-6, 20:3 n-6, 22:0, 22:6 n-3 and 24:0, several FA concentrations were influenced by the sampling period. In fact, compared with milk collected in the 9th week of lactation and in 


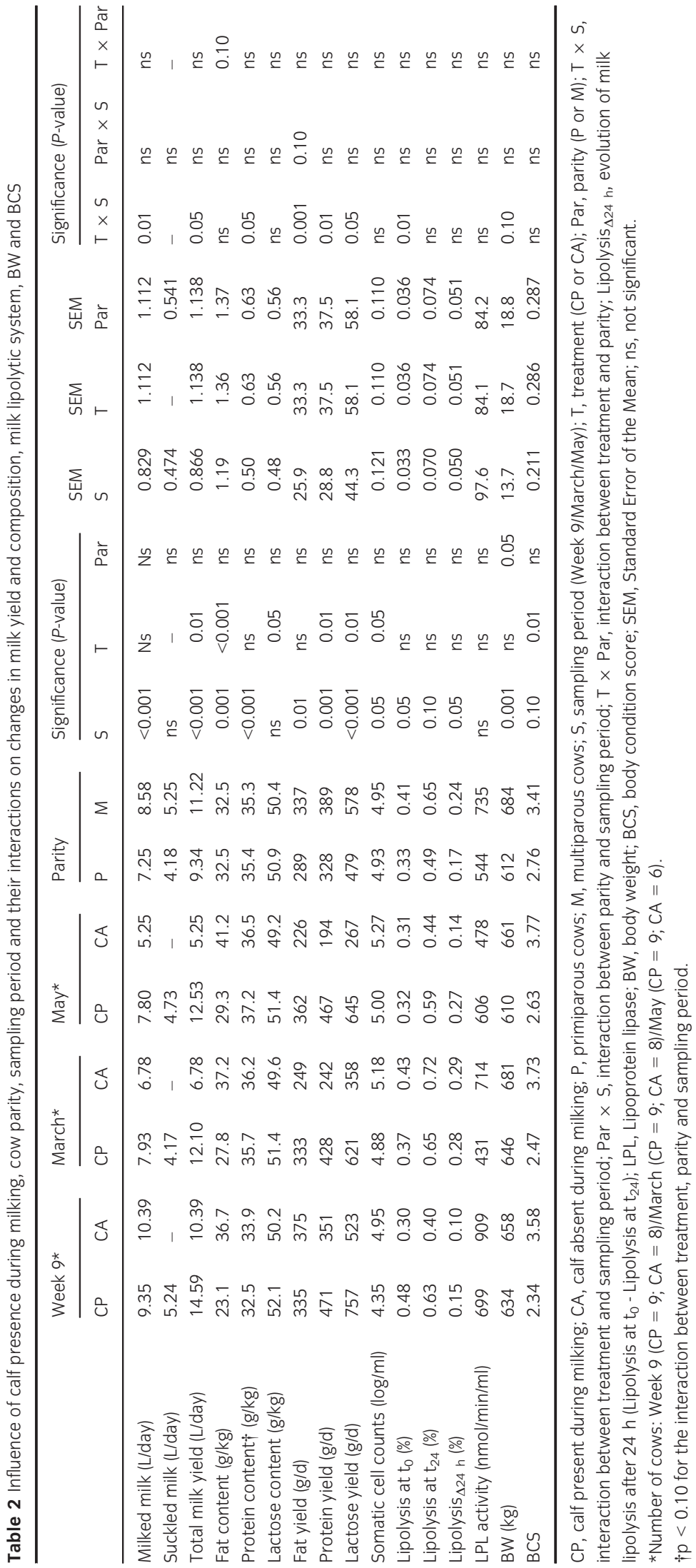




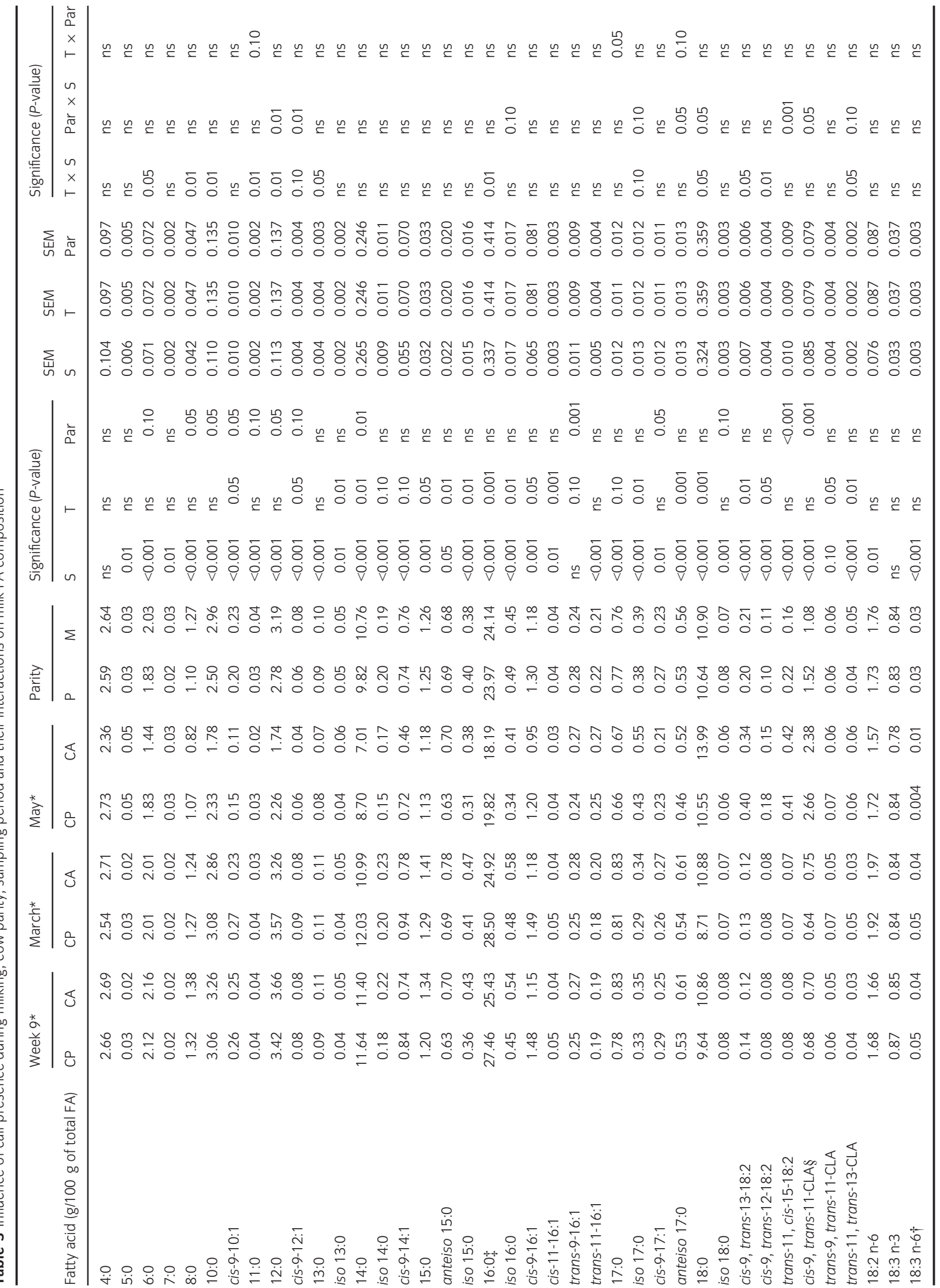




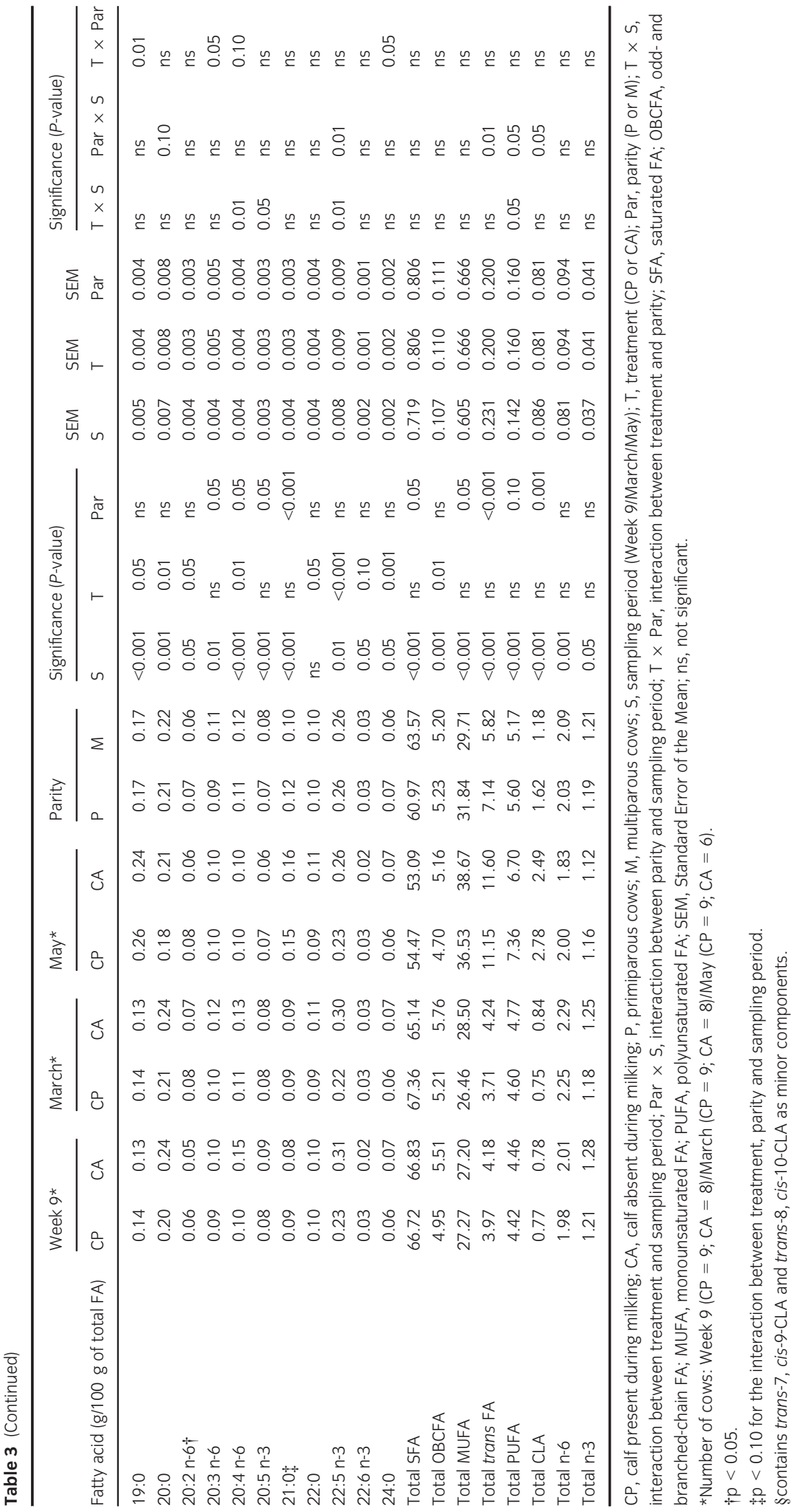




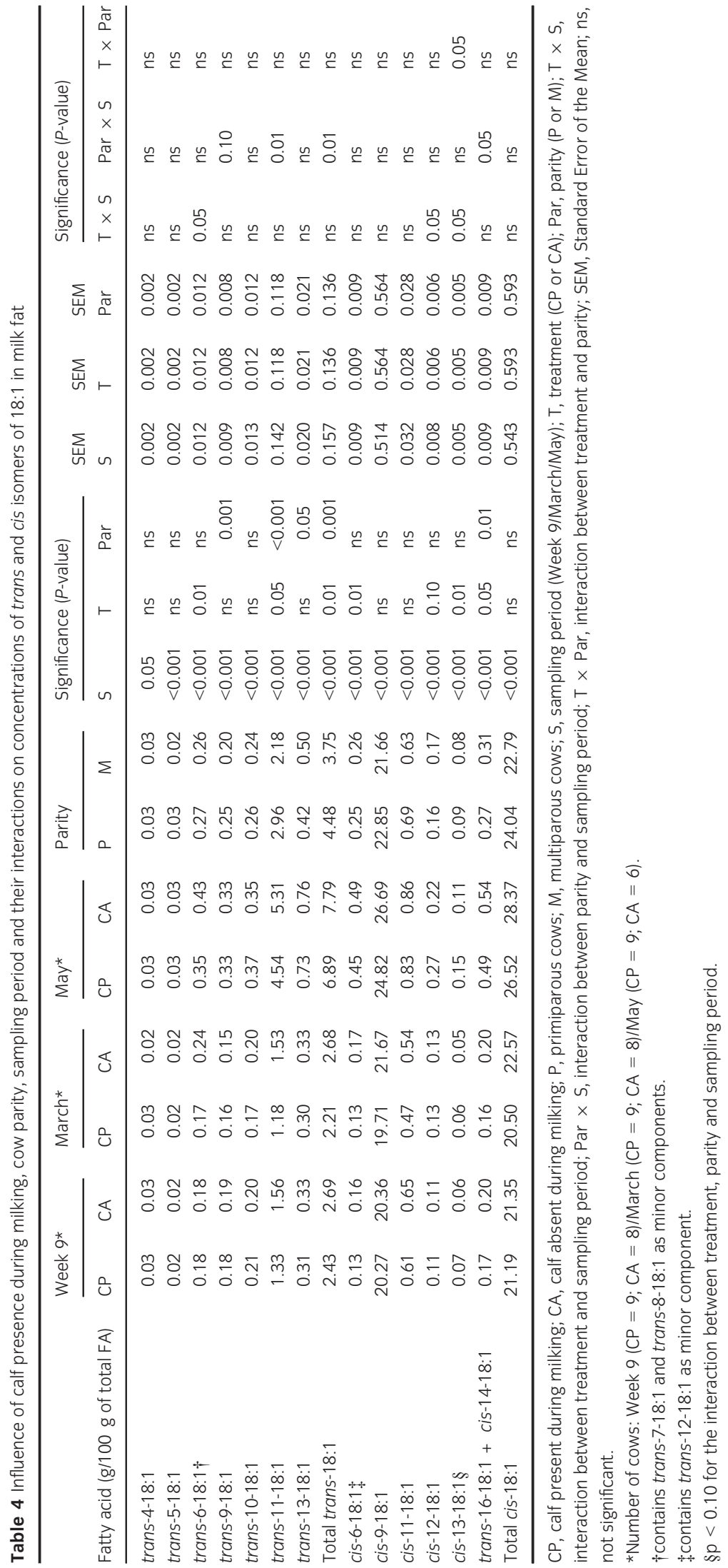


March, milk collected during the grazing season had higher concentrations of 5:0 $(p<0.01)$, 7:0 $(p<0.01), 19: 0(p<0.001)$, total monounsaturated FA (MUFA) $(\mathrm{p}<0.001)$ and trans-11-16:1 $(\mathrm{p}<$ $0.001)$. Moreover, milk collected during the grazing season had the highest concentrations of cis $(6,9$, and $11)$ and trans $(4,5,10$, and 13) isomers of 18:1. In contrast, milk collected during the grazing season had lower concentrations of certain individual saturated FA (SFA) [14:0 (p<0.001), iso 14:0 (p<0.001), 15:0 $(\mathrm{p}<0.001)$, anteiso 15:0 $(\mathrm{p}<0.05)$, iso 15:0 ( $<<0$. $001)$, 17:0 ( $\mathrm{p}<0.001)$, iso 18:0 $(\mathrm{p}<0.001)]$, total SFA $(\mathrm{p}<0.001)$, total OBCFA $(\mathrm{p}<0.001)$, individual MUFA [cis-9-10:1 ( $p<0.001)$, cis-9-14:1 ( $<<0.001)$, cis-9-16:1 ( $\mathrm{p}<0.001)$, cis-9-17:1 $(\mathrm{p}<0.01)], 18: 2 \mathrm{n}-6$ $(\mathrm{p}<0.01)$, total $\mathrm{n}-6(\mathrm{p}<0.001)$ and total $\mathrm{n}-3$ FA $(\mathrm{p}<0.05)$ compared with milk collected during the 2 dates during the winter season.

\section{Effect of parity}

The multiparous Salers cows had higher milk concentrations of total SFA $(p<0.05), 8: 0(p<0.05), 10: 0$ $(\mathrm{p}<0.05), \quad 14: 0 \quad(\mathrm{p}<0.01), \quad$ cis-9-10:1 $\quad(\mathrm{p}<0.05)$, trans-13-18:1 $(\mathrm{p}<0.05)$ and 20:5 n-3 $(\mathrm{p}<0.05)$ than the primiparous Salers cows. Moreover, the milk fat of the multiparous Salers cows had lower concentrations of total MUFA ( $\mathrm{p}<0.05)$, trans-9-16:1 $(\mathrm{p}<0.001)$ and cis-9-17:1 $(\mathrm{p}<0.05)$ than that of the primiparous Salers cows.

\section{Effect of treatment $\times$ sampling period and parity $\times$ sampling period interactions}

Several significant interactions between treatment and sampling period are reported in Tables 3 and 4 . In particular, the calf presence increased the 16:0 concentration $(p<0.01)$ more markedly in milk collected in March than in that collected during the 9th week of lactation and the grazing season. In contrast, the calf presence more markedly decreased the concentration of 18:0 $(p<0.05)$ in milk fat during the grazing season than during the two dates of winter season, whereas the calf presence decreased the milk 22:5 n-3 $(\mathrm{p}<0.01)$ concentration more markedly during the winter season than during the grazing season.

Parity had significant effect on several milk FA concentrations according to the sampling period (12:0, 18:0, 20:0, cis-9-12:1, iso 16:0, anteiso 17:0, trans-9-, trans-11-, and cis-14-18:1, trans-11, trans-13-CLA and $22: 5 \mathrm{n}-3)$. In particular, the milk concentrations of trans-11, cis-15-18:2, cis-9, trans-11-CLA, total trans18:1, total CLA, total trans FA and total polyunsaturated FA (PUFA) from the primiparous cows were higher than those from the multiparous cows, with a more marked difference during the grazing season.

\section{Milk lipolytic system}

\section{Effect of calf presence during milking}

The presence of the calf had no influence on milk lipolysis and lipoprotein lipase (LPL) activity. It increased the initial free FA (FFA) concentrations in milk collected in the 9th week of lactation, decreased the initial FFA concentrations in milk collected in March and did not change the initial FFA concentrations in milk collected during the grazing season (treatment $\times$ sampling period interaction, $\mathrm{p}<0.01)$.

\section{Effect of sampling period}

Initial lipolysis was greater during the winter season than during the grazing season $(p<0.05)$. In contrast, LPL activity was not affected by the sampling period.

Bulk milk and cheese composition and yield

The fat and protein contents of CP native bulk milk were lower $(-14.4 \mathrm{~g} / \mathrm{kg}$ and $-1.3 \mathrm{~g} / \mathrm{kg}$, respectively) than those of CA milk (Table 5). When the milk was not standardised before cheesemaking, CP native bulk milk resulted in cheeses with a lower DM and fat contents $(-2 \%$ and $-7.6 \%$, respectively) and a higher total $\mathrm{N}$ in $\mathrm{DM}(+1.4 \%)$, respectively. The gross and dry cheese yields were significantly higher for CA than CP cheeses. When the milk was standardised before cheesemaking, the above-mentioned differences between CA and CP cheeses were not observed.

\section{Discussion}

\section{Milk yield and composition}

\section{Effect of calf presence during milking}

The present study showed a significant higher total milk yield from cows milked in the presence of the calf, in agreement with Cozma et al. (2013), who reported a higher milk yield (+5.6 l/day) for primiparous Salers cows milked in the presence of the calf. Our results also agree with Tournadre et al. (2008), who compared Salers cows suckled before milking with Salers cows for which only the visual presence of the calf (without physical contact with the cow) was allowed before and during milking. Moreover, Álvarez-Rodríguez et al. (2010) have observed that ad libitum nursing in Parda de Montaña cows allowed a higher milk yield $(+1.7 \mathrm{~kg} /$ day $)$ 
Table 5 Influence of calf presence during milking and milk standardisation on bulk milk and cheese composition and yield

\begin{tabular}{|c|c|c|c|c|c|c|c|c|}
\hline & \multicolumn{2}{|c|}{ Native milk } & \multicolumn{2}{|c|}{ Standardised milk } & \multirow[b]{2}{*}{ SEM } & \multicolumn{3}{|c|}{ Significance (P-value) } \\
\hline & $\mathrm{CP}$ & CA & $\mathrm{CP}$ & CA & & T & M & $\mathrm{T} \times \mathrm{M}$ \\
\hline \multicolumn{9}{|l|}{ Bulk milk composition } \\
\hline Fat content (g/kg) & $24.9^{\mathrm{a}}$ & $39.3^{c}$ & $36.4^{\mathrm{b}}$ & $36.1^{\mathrm{b}}$ & 1.37 & $<0.001$ & $<0.001$ & $<0.001$ \\
\hline Protein content $(\mathrm{g} / \mathrm{kg})$ & $34.2^{\mathrm{ab}}$ & $35.5^{c}$ & $33.8^{a}$ & $35.3^{\mathrm{ab}}$ & 0.80 & $<0.01$ & ns & ns \\
\hline Somatic cell counts $\left(\log _{10} / \mathrm{ml}\right)$ & $4.4^{\mathrm{a}}$ & $4.9^{\mathrm{b}}$ & $4.5^{\mathrm{a}}$ & $5.0^{b}$ & 0.13 & $<0.001$ & ns & ns \\
\hline \multicolumn{9}{|l|}{ Cheese composition } \\
\hline DM $(\%)$ & $60.8^{\mathrm{a}}$ & $62.8^{\mathrm{b}}$ & $62.5^{\mathrm{b}}$ & $62.2^{\mathrm{b}}$ & 0.83 & $<0.10$ & ns & $<0.05$ \\
\hline Fat $(\%)$ & $24.8^{\mathrm{a}}$ & $32.4^{c}$ & $31.6^{\mathrm{bc}}$ & $30.8^{\mathrm{b}}$ & 0.61 & $<0.001$ & $<0.001$ & $<0.001$ \\
\hline Fat in DM (\%) & $39.9^{\mathrm{a}}$ & $50.1^{c}$ & $48.8^{c}$ & $47.4^{b}$ & 0.90 & $<0.001$ & $<0.001$ & $<0.001$ \\
\hline Total N in DM (\%) & $7.82^{c}$ & $6.39^{a}$ & $6.69^{b}$ & $6.75^{b}$ & 0.116 & $<0.001$ & $<0.001$ & $<0.001$ \\
\hline \multicolumn{9}{|l|}{ Cheese yield } \\
\hline Gross (\%) & $7.78^{\mathrm{a}}$ & $9.17^{c}$ & $8.38^{b}$ & $8.52^{\mathrm{b}}$ & 0.371 & $<0.01$ & ns & $<0.01$ \\
\hline Dry (\%) & $4.73^{\mathrm{a}}$ & $5.75^{c}$ & $5.24^{b}$ & $5.30^{b}$ & 0.235 & $<0.001$ & ns & $<0.01$ \\
\hline
\end{tabular}

$\mathrm{CP}$, calf present during milking; $\mathrm{CA}$, calf absent during milking; $\mathrm{T}$, treatment (CP or $\mathrm{CA}$ ); $\mathrm{M}$, milk nature (native or standardised); $\mathrm{T} \times \mathrm{M}$, interaction between treatment and milk nature; DM, dry matter; gross yield: mass of ripened cheese/mass of bulk tank milk $\times 100$; dry yield: (dry extract end ripening $\times$ mass of ripened cheese)/mass of bulk tank milk $\times 100$; SEM, Standard Error of the Mean; ns, not significant.

${ }^{a-c}$ Within-row means with different letters differ at a threshold of $5 \%$.

than nursing only once daily. The higher total milk yield of Salers cows milked in the presence of the calf may be attributed to the contribution of residual milk to total milk production, the former being the fraction of milk suckled by the calf (Cozma et al., 2013). Moreover, the higher milk yield observed when calf is present could be due to a higher oxytocin-mediated milk ejection reflex initiated by the presence of the suckling young through nervous stimulation of the udder (Tančin et al., 2001; Tournadre et al., 2008), allowing a better emptying of the mammary gland. In contrast to our results, Mendoza et al. (2010) observed a decrease in milk yield from Holstein cows with the calf presence, whereas De Passillé et al. (2008) reported no effect of the calf presence during milking on milk production in Holstein cows.

The principal effect of the calf presence during milking was a decrease in milk fat content, in agreement with Cozma et al. (2013) with Salers cows and Mendoza et al. (2010) with Holstein cows. Moreover, nursing ad libitum induced a lower milk fat content in Parda de Montaña cows than nursing once daily (Álvarez-Rodríguez et al., 2010). A lower fat content in milked milk in CP cows may be related to the removal of residual milk (alveolar milk) by the calves. This fraction of the milk is richer in fat than the cisternal milk (available milk), which corresponds to the milk obtained after milking (Fröberg et al., 2008). Moreover, Tournadre et al. (2008) have shown that the fat content in milked milk was lower if cow-calf contact was reduced in Salers cows.
The calf presence decreased milk SCC in our study in agreement with Cozma et al. (2013). This could be attributed to a beneficial effect of calf suckling on udder health, probably through a better udder emptying or due to presence of bacterial inhibitors in calf saliva (Fröberg et al., 2008). Another explanation could be due to the fact that the calf drinking the residual milk, which is the fraction of milk with the highest SCC, induced a decrease in the SCC of the milked milk, corresponding to the cisternal milk (Sarikaya et al., 2005).

\section{Effect of sampling period}

The milk yield of the Salers cows was significantly lower during the grazing than during the winter season. The primary reason for this difference could be due to the advanced stage of lactation during this period of the experiment (Khanal et al., 2008). Moreover, the milk fat and protein contents were higher during the grazing than during the winter season, in agreement with Khanal et al. (2008) and in disagreement with White et al. (2001) and Lerch et al. (2012a). This difference might be explained by a concentration effect because milk yield was lower during the grazing than during the winter season.

The present study reported higher SCC in milks collected on grazing than on winter season, whereas White et al. (2001) showed no significant differences in SCC between indoor and grazing season. The difference reported by our study may be due to the advanced stage of lactation of cows during the grazing season because late-lactation cows are more likely to develop high SCC (Olde Riekerink et al., 2007). 


\section{Milk fatty acid composition}

Effect of calf presence during milking

The decrease in the milk concentrations of several OBCFA, FA with 18 carbon atoms (18:0, cis-6-18:1, cis-14-18:1, trans-11-18:1) and 22:5 n-3 in the presence of the calf can be explained by a higher fat content in the milk suckled by the calf (Mendoza et al., 2010). Similar results have been reported by Cozma et al. (2013), who studied the influence of calf presence during milking on the FA profile in bulk milk from primiparous Prim'Holstein and Salers cows. Moreover, McKusick et al. (2002) showed in ewes that 18:1 FA concentration tended to be higher in the alveolar milk, suckled by the offspring, compared with the cisternal milk.

\section{Effect of sampling period}

The sampling period appears to be the main factor affecting milk FA composition although there are overlapping effects such as nature of forage, stage of lactation, photoperiod and temperature.

The milk from the grazed grass contained less shortand medium-chain FA (SMCFA) (from 6:0 to 16:0) than the milk from the winter diets based on concentrate and hay. This result is consistent with Ferlay et al. (2006), who have shown that the SMCFA concentration in milk fat from cows grazed on young grass was significantly less important than that from cows fed a high-forage diet. This decrease is due, in part, to the inhibitory effect of dietary PUFA provided in higher amounts by the pasture diet on acetyl-CoA carboxylase activity in the mammary gland (Chilliard and Ferlay, 2004). Likewise, the concentration of most OBCFA was lower during the grazing season than during the winter season. This difference could be linked to the inhibitory effect of the PUFA provided in important amounts by pasture on the activity or number of rumen bacteria that synthesised OBCFA (Vlaeminck et al., 2006).

An increase in the milk concentrations of 18:0 $(+2.3 \mathrm{~g} / 100 \mathrm{~g})$, cis-9-18:1 (+5.3 g/100 g) and trans$11-18: 1(+3.5 \mathrm{~g} / 100 \mathrm{~g})$ during the grazing season is typically observed in cows grazing pasture vs. cows fed winter diets (Ferlay et al., 2006; Lerch et al., $2012 \mathrm{~b}$ ), and these FA are final product and intermediates of the ruminal biohydrogenation of PUFA provided by the pasture diet (Chilliard et al., 2007). Moreover, the lowest milk 18:0 concentration during winter season could be due also to low ruminal biohydrogenation observed with diets based on hay (Chilliard et al., 2007). Milk 18:0 and cis-9-18:1 could also originate from body-fat mobilisation, as suggested by the decrease in BW during the grazing season. This outcome could be due to the increased energy expenditure by cows resulting from walking during the grazing season (Chilliard et al., 2003). The stage of lactation could also partly influence the cis-9, trans11-CLA concentration, as Lawless et al. (1999) have reported a slight increase $(+1.23 \mathrm{~g} / 100 \mathrm{~g})$ in cis-9, trans-11-CLA content from 75 and 120 days in milk from grazing cows of different breeds.

Surprisingly, the nature of the diet had no effect on the milk 18:3 n-3 concentration, whereas most published studies have reported higher values for pasture diets than for winter diets (Dewhurst et al., 2006). One explanation could be that the diets in our study were rich in grass during the entire experimental period.

\section{Effect of parity}

The influence of parity on the milk FA composition was minor in the present study relative to the effects of sampling period and treatment. We observed lower milk concentrations of trans-11-18:1 (-0.78 g/100 g) and cis-9, trans-11-CLA $(-0.44 \mathrm{~g} / 100 \mathrm{~g})$ from the multiparous than from the primiparous cows, in contrast to Kelsey et al. (2003), who have reported no effect of parity on these milk FA concentrations from Holstein and Brown Swiss cows under the same feeding practices.

Overall, the milk fat from the multiparous cows was richer in SMCFA with 8-14 carbons and poorer in long-chain FA with up to 18 carbons than that from the primiparous cows. This difference could be due, in part, to the higher level of fatty acid synthetase in the mammary tissue of multiparous than that of primiparous cows reported by Miller et al. (2006), which suggested that the mammary gland of multiparous cows is more active for the de novo synthesis of SMCFA. The differences in the milk FA profile between cows according to the parity could also be linked to a higher proportion of grass in the diet ingested by the primiparous than by the multiparous cows because dietary PUFA are powerful inhibitors of de novo lipogenesis in the mammary gland (Chilliard and Ferlay, 2004).

Whatever the sampling period, the milk fat from the primiparous cows had higher concentrations of several intermediates of PUFA biohydrogenation (trans-18:1, total CLA, total trans FA, trans-11, cis-1518:2 and cis-9, trans-11-CLA) than that from the multiparous cows, suggesting a less-complete ruminal PUFA biohydrogenation in the primiparous cows. 


\section{Milk lipolytic system}

Effect of calf presence during milking

In the present study, calf presence increased initial lipolysis for the cows milked during the 9th week of lactation and slightly decreased it for the cows milked in March, whereas it had no influence on initial lipolysis for the cows milked during the grazing season. Nevertheless, the presence of the calf had no influence on lipolysis measured after $24 \mathrm{~h}$ or on LPL activity. Our results agree only in part with Cozma et al. (2013), who noted in Salers cows (DIM $=40-70)$ that initial lipolysis and lipolysis after $24 \mathrm{~h}$ were increased by the presence of the calf. Moreover, Tournadre et al. (2008), using Salers cows, reported no significant effect of cow-calf contact on initial lipolysis, whereas lipolysis after $24 \mathrm{~h}$ was higher for cows for which no physical contact with the calf was allowed than for cows suckled before milking. In our study, the high initial lipolysis in the presence of the calf for milk collected on the 9th week of lactation could be due, in part, to suckling by the offspring. Suckling can cause milk agitation in the udder, known as one factor inducing lipolysis (Deeth, 2006).

\section{Effect of sampling period}

In our study, initial lipolysis was more important in milk collected during the winter season than in that collected during the grazing season. Our results agree with Lerch et al. (2012a) and Chilliard and Lamberet (1984). Nevertheless, the results of the present study are contradictory to the results of Ferlay et al. (2006) with Tarentaise and Montbéliarde cows, which showed no difference in milk lipolysis between grazing cows and cows fed mountain natural grassland hay at the same time.

\section{Effect of parity}

Cow parity had no influence on milk lipolysis and LPL activity in the present study, in disagreement with Chilliard and Lamberet (1984), who have reported that lipolysis was higher for primiparous than for multiparous cows. The lack of a parity effect could be linked to the low difference in milk yield between the primiparous and multiparous cows in our study and the slight number of animals per group.

Bulk milk composition, cheese composition and yield

CA native bulk milk had higher fat content than CP native bulk milk. As a consequence, the fat content of cheese made from CA native bulk milk was significantly higher than that made from CP native bulk milk. Indeed, the fat content of cheese is primarily influenced by the fat content of native milk and by its ability to be retained in curd (Cattani et al., 2014). The higher fat content of the CA native bulk milk explains also the higher cheese yield obtained. This result is in agreement with many previous studies reporting evidence that there is an increase in cheese yield when fat content is higher (Guinee et al., 2007; Martin et al., 2009). The slight higher protein content of CA milk could also explain partly the higher cheese yield of CA native milk, but its contribution seems marginal compared to the fat because when the milk fat is standardised, the cheese yield differences between CA and CP are not significant.

\section{Conclusions}

Removing the calf during the milking of the Salers cows decreased the total milk yield, but did not change the milked milk. It also increased considerably the milk fat content, as well as the cheese yield and the fat content of the resulting ripened cheeses. Calf removal had higher effects on dairy performance, cheese yield and composition than on milk FA composition and lipolysis. Throughout the experimental period, removing the calf decreased the milk concentrations of 16:0, whereas it increased milk total OBCFA concentrations. Calf removal only decreased initial lipolysis in milk collected during the 9th week of lactation. Therefore, changing the traditional milking system of Salers cows by removing the calf during milking seems a feasible alternative for dairy farmers interested to simplify the milking routine and to improve cheese yield and composition. Nevertheless, this milking alternative could be accomplished only if it is possible to select cows having the capacity to be milked easily without the calf.

Furthermore, the influence of the presence of the calf during milking on the milk fat characteristics was lower than that of the sampling period. Indeed, compared with the winter diet, the pasture diet increased milk 18:0, cis-9-18:1, trans-11-18:1 and cis-9, trans-11CLA concentrations, whereas it decreased the milk medium-chain FA and OBCFA concentrations, indicating that pasture could modify the milk concentrations of FA with putative nutritional effects on human health, as previously demonstrated in Holstein cows.

\section{Acknowledgements}

The authors thank G. Juttier for the follow-up of the experiment, the technical staff of UEMA for animal care, D. Bany, C. Labonne and E. Tixier for help with 
laboratory analyses. The authors also thank B. Faure (Groupe Salers Evolution) who managed the PSDR (Pour et Sur le Développement Régional) programme 2007-2011 that supported this research. This manuscript was published under the frame of the European Social Fund, Human Resources Development Operational Programme 2007-2013, project No. POSDRU/159/1.5/S/136893.

\section{References}

Agabriel, J.; Faure, B.; Lebreton, F. X.; Lherm, M.; Micol, D.; Garcia-Launay, F.; Pradel, P.; Angeon, V.; Martin, B., 2014: La race bovine Salers: un atout pour le développement de son territoire d'origine par son identité forte et des produits qualifiés. Cahiers Agricoles 23, 138-147.

Álvarez-Rodríguez, J.; Palacio, J.; Sanz, A., 2010: Effects of nursing frequency and parity on the productive, metabolic and reproductive parameters of beef cows. Livestock Science 129, 111-121.

AOAC (Association of Official Analytical Chemists), 1997: Official Methods of Analysis 16th edn. AOAC Int, Gaithersburg, MD, USA.

Cattani, M.; Mantovani, R.; Schiavon, S.; Bittante, G.; Bailoni, L., 2014: Recovery of $n-3$ polyunsaturated fatty acids and conjugated linoleic acids in ripened cheese obtained from milk of cows fed different levels of extruded flaxseed. Journal of Dairy Science 97, 123-135. Chilliard, Y.; Ferlay, A., 2004: Dietary lipids and forages interactions on cow and goat milk fatty acid composition and sensory properties. Reproduction Nutrition Development 44, 467-492.

Chilliard, Y.; Lamberet, G., 1984: La lipolyse dans le lait: les différents types, mécanismes, facteurs de variation, signification pratique. Le Lait 64, 544-578.

Chilliard, Y.; Ferlay, A.; Rouel, J.; Lamberet, G., 2003: A review of nutritional and physiological factors affecting goat milk lipid synthesis and lipolysis. Journal of Dairy Science 86, 1751-1770.

Chilliard, Y.; Glasser, F.; Ferlay, A.; Bernard, L.; Rouel, J.; Doreau, M., 2007: Diet, rumen biohydrogenation and nutritional quality of cow and goat milk fat. European Journal of Lipid Science and Technology 109, 828-855.

Cozma, A.; Martin, B.; Guiadeur, M.; Pradel, P.; Tixier, E.; Ferlay, A., 2013: Influence of calf presence during milking on yield, composition, fatty acid profile and lipolytic system of milk in Prim'Holstein and Salers cow breeds. Dairy Science $\theta$ Technology 93, 99-113.
De Passillé, A. M.; Marnet, P. G.; Lapierre, H.; Rushen, J., 2008: Effects of twicedaily nursing on milk ejection and milk yield during nursing and milking in dairy cows. Journal of Dairy Science 91, 1416-1422.

Deeth, H. C., 2006: Lipoprotein lipase and lipolysis in milk. International Dairy Journal 16, 555-562.

Dewhurst, R. J.; Shingfield, K. J.; Lee, M. R. F.; Scollan, N. D., 2006: Increasing the concentrations of beneficial polyunsaturated fatty acids in milk produced by dairy cows in high-forage systems. Animal Feed Science and Technology 131, 168-206.

Faulconnier, Y.; Thévenet, M.; Fléchet, J.; Chilliard, Y., 1994: Lipoprotein lipase and metabolic activities in incubated bovine adipose tissue explants: effects of insulin, dexamethasone, and fetal bovine serum. Journal of Animal Science 72, 184-191.

Ferlay, A.; Martin, B.; Pradel, P.; Coulon, J. B.; Chilliard, Y., 2006: Influence of grass-based diets on milk fatty acid composition and milk lipolytic system in Tarentaise and Montbéliarde cow breeds. Journal of Dairy Science $\mathbf{8 9}$, 4026-4041.

Ferlay, A.; Martin, B.; Lerch, S.; Gobert, M.; Pradel, P.; Chilliard, Y., 2010: Effects of supplementation of maize silage diets with extruded linseed, vitamin $\mathrm{E}$ and plant extracts rich in polyphenols, and morning v. evening milking on milk fatty acid profiles in Holstein and Montbéliarde cows. Animal 4, 627-640.

Ferlay, A.; Doreau, M.; Martin, C.; Chilliard, Y., 2013: Effects of incremental amounts of extruded linseed on the milk fatty acid composition of dairy cows receiving hay or corn silage. Journal of Dairy Science 96, 6577-6595.

Fröberg, S.; Gratte, E.; SvennerstenSjaunja, K.; Olsson, I.; Berg, C.; Orihuela, A.; Galina, C. S.; García, B.; Lidfors, L., 2008: Effect of suckling ('restricted suckling') on dairy cows' udder health and milk let-down and their calves' weight gain, feed intake and behaviour. Applied Animal Behaviour Science 113, 1-14.
Guinee, T. P.; Mulholland, E. O.; Kelly, J.; Callaghan, D. J. O., 2007: Effect of protein-to-fat ratio of milk on the composition, manufacturing efficiency, and yield of Cheddar cheese. Journal of Dairy Science 90, 110-123.

INRA (Institut National de la Recherche Agronomique), 2007: Alimentation des Bovins, Ovins et Caprins. Besoins des Animaux - Valeurs des Aliments - Tables. Quae Editions, Versailles, France.

Institut de l'Elevage, 2011: Résultats de Contrôle Laitier France 2011. Available at: http://idele.fr/filieres/bovins-lait/ publication/idelesolr/recommends/ resultats-de-controle-laitier-france$2011 . h t m l$.

Jellema, A., Anderson, M., Heeschen, W, Kuzdzal Savoie, S., Needs, E.C., Suhren, G., Van Reusel, A., 1991: Determination of free fatty acids in milk and milk products. Bulletin of the International Dairy Federation, no. 265. International Dairy Federation, Brussels, Belgium.

Kelsey, J. A.; Corl, B. A.; Collier, R. J.; Bauman, D. E., 2003: The effect of breed, parity, and stage of lactation on conjugated linoleic acid (CLA) in milk fat from dairy cows. Journal of Dairy Science 86, 2588-2597.

Khanal, R. C.; Dhiman, T. R.; Boman, R. L., 2008: Changes in fatty acid composition of milk from lactating dairy cows during transition to and from pasture. Livestock Science 114, 164-175.

Lawless, F.; Stanton, C.; L'Escop, P.; Devery, R.; Dillon, P.; Murphy, J. J., 1999: Influence of breed on bovine milk cis-9, trans-11-conjugated linoleic acid content. Livestock Production Science 62, 4349.

Le Neindre, P.; Dubroeucq, H., 1973: Observations sur l'estimation de la production laitière des vaches allaitantes par la pesée du veau avant et après la tétée. Annales de Zootechnie 22, 413-422. Lerch, S.; Ferlay, A.; Pomiès, D.; Martin, B.; Pires, J. A. A.; Chilliard, Y., 2012a: Rapeseed or linseed supplements in grass-based diets: Effects on dairy performance of Holstein cows over 2 consecutive lactations. Journal of Dairy Science 95, 1956-1970. 
Lerch, S.; Ferlay, A.; Shingfield, K. J.; Martin, B.; Pomiès, D.; Chilliard, Y., 2012b: Rapeseed or linseed supplements in grass-based diets: effects on milk fatty acid composition of Holstein cows over two consecutive lactations. Journal of Dairy Science 95, 5221-5241.

Martin, B.; Pomiès, D.; Pradel, P.; VerdierMetz, I.; Rémond, B., 2009: Yield and sensory properties of cheese made with milk from Holstein or Montbéliarde cows milked twice or once daily. Journal of Dairy Science 92, 4730-4737.

McKusick, B. C.; Thomas, D. L.; Romero, J. E.; Marnet, P. G., 2002: Effect of weaning system on milk composition and distribution of milk fat within the udder of East Friesian dairy ewes. Journal of Dairy Science 85, 2521-2528.

Mendoza, A.; Cavestany, D.; Roig, G.; Ariztia, J.; Pereira, C.; La Manna, A.; Contreras, D. A.; Galina, C. S., 2010 : Effect of restricted suckling on milk yield, composition and flow, udder health, and postpartum anoestrus in grazing Holstein cows. Livestock Science 127, 60-66.
Miller, N.; Delbecchi, L.; Petitclerc, D.; Wagner, G. F.; Talbot, B. G.; Lacasse, P., 2006: Effect of stage of lactation and parity on mammary gland cell renewal. Journal of Dairy Science 89, 4669-4677.

Olde Riekerink, R. G. M.; Barkema, H. W.; Stryhn, H., 2007: The effect of season on somatic cell count and the incidence of clinical mastitis. Journal of Dairy Science 90, 1704-1715.

Rowland, S. J., 1938: The determination of the nitrogen distribution in milk. Journal of Dairy Research 9, 42-46.

Sarikaya, H.; Werner-Misof, C.; Atzkern, M.; Bruckmaier, R. M., 2005: Distribution of leucocyte populations, and milk composition, in milk fractions of healthy quarters in dairy cows. Journal of Dairy Research 72, 486-492.

SAS (Statistical Analysis System), 2003. SAS/STAT User's Guide. Version 9.1 edn. SAS Institute Inc., Cary, NC, USA.

Sukhija, S. P.; Palmquist, D. L., 1988: Rapid method for determination of total fatty acid content and composition of feedstuffs and feces. Journal of Agricultural and Food Chemistry 36, 1202-1206.
Tančin, V.; Kraetzl, W. D.; Schams, D.; Bruckmaier, R. M., 2001: The effects of conditioning to suckling, milking and of calf presence on the release of oxytocin in dairy cows. Applied Animal Behaviour Science 72, 235-246.

Tournadre, H.; Veissier, I.; Martin, B.; Garel, J. P., 2008: Influence of cow-calf contact before milking and motheryoung relationship on yield and composition of milk in Salers cows. Rencontres Recherches Ruminants 15, 159-162.

Veissier, I., 1999: Expérimentation animale: biologie, éthique, réglementation. INRA Productions Animales 12, 365-375.

Vlaeminck, B.; Fievez, V.; Cabrita, A. R. J.; Fonseca, A. J. M.; Dewhurst, R. J., 2006: Factors affecting odd- and branchedchain fatty acids in milk: a review. Animal Feed Science and Technology 131, 389-417.

White, S. L.; Bertrand, J. A.; Wade, M. R.; Washburn, S. P.; Green, J. T. Jr; Jenkins, T. C., 2001: Comparison of fatty acid content of milk from Jersey and Holstein cows consuming pasture or a total mixed ration. Journal of Dairy Science 84, 2295-2301. 